\title{
Pengaruh Sosialisasi Partai Politik Terhadap Partisipasi Pemilih umum Pada Pemilihan Bupati 2017 Di Kelurahan Busoa Kecamatan Batauga Kabupaten Buton Selatan
}

\author{
Ansar Suherman ${ }^{1}$ \\ Fakultas Ilmu Sosial dan Ilmu Politik Universitas Muhammadiyah Buton \\ Email: ansar.suherman@gmail.com
}

\begin{abstract}
ABSTRAK
Tiap pelaksanaan pemilu tentu akan terdapat perbedaan jumlah pemilih berdasarkan jumlah penduduk yang terdaftar sebagai pemilih. Salah satunya yakni baik dipengaruhi pengurangan jumlah pemilih karena adanya jumlah kematian, maupun adanya penambahan jumlah daftar pemilih karena adanya pemilih baru atau pemilih pemula, Mengingat pemilih umum merupakan pemilih yang sangat potensial dalam perolehan suara pada pemilu. Permasalahan ini juga dirasa telah menjadi permasalahan yang sama di berbagai daerah termasuk Kabuputen Buton Selatan sebagai daerah otonomi baru Jenis Penilitian yang digunakan dalam penyusunan Proposal ini adalah jenis penilitian kuantitatif dengan menggunakan data-data yang berhubungan dengan jumlah pemilih umum tahun 2017 di keluarahan Busoa kecamatan Batauga kabupaten Buton Selatan. metode kuantitatif adalah pendekatan ilmiah yang memandang suatu realitas itu dapat diklasifikasikan, konkrit, teramati dan terukur,hubungan variabelnya bersifat sebab akibat dimana data penelitiannya berupa angka-angka dan analisisnya menggunakan statistik. Penelitian dilakukan di dalam paradigma kuantitatif. Penelitian ini difokuskan pengaruh sosialisasi partai politik terhadap partisipasi pemilih umum pada pemilihan Bupati 2017 di Kelurahan Busoa Kecamatan Batauga Kabupaten Buton Selatan Hasil uji hipotesis dengan menggunakan uji-t menujukan bahwa Thitung pada variabel sosialisasi partai politik yaitu sebesar 6,231 dan signifikan pada angka 0,000. Dimana nilai signifikan lebih kecil dibandingkan angka signifikasi yang ditetapkan $(0,000<0,05)$. Maka dapat ditarik kesimpulan H1 diterima dan Ho di tolak. Artinya bahwa terdapat pengaruh yang positif antara variabel sosialisasi partai politik terhadap partisipasi pemilih umum.
\end{abstract}

Kata Kunci: Sosialisasi, Politik, Partai, Partisipasi Pemilih.

\section{The Influence of Socialization of Political Parties Against Public Voter Participation in the 2017 Regent Election in Busoa Village, Batauga District, South Buton Regency}

\begin{abstract}
Each election will certainly have a difference in the number of voters based on the number of residents registered as voters. One of them is influenced both by the reduction in the number of voters due to the number of deaths, and by the sum of the number of voters due to the presence of new voters or beginning voters, considering that general voters are very likely voters in the choice. It was also considered that this problem had become the same problem in several regions, such as South Buton Regency as a new autonomous region. The type of research used in the preparation of this proposal was quantitative research with data regarding the number of voters in general in 2017 in the sub-district of Busoa in the sub-district of Batauga. District of South Buton. The quantitative method is a scientific approach that sees a reality that can be classified, concrete, observable and measurable, the variable relationship is causal where the research data are in the form of numbers and the analysis uses statistics. The research is carried out within the quantitative paradigm. This study focused on the influence of the socialization of political parties on the general participation of voters in the 2017 Regent elections in Busoa Village, Batauga Subdistrict, South Buton District. The results of the hypothesis tests using the t test showed that Tcount in the socialization variable of the political parties was 6,231 and was significant in 0,000. Where the value is significantly less than the specified significance number $(0.000<0.05)$. Then it can be concluded that HI is accepted and Ho is rejected. This means that there is a positive influence between the socialization variables of the political parties in the general participation of the voters.
\end{abstract}

Keywords: Socialization, Politics, Party, Voter Participation.

Submitted: Februari 2018, Accepted: Agustus 2018, Published: Februari 2018

ISSN: 2303-2006 
Korespondensi: Ansar Suherman, S.I.P., M.I.Kom. Universitas Muhammadiyah Buton. Alamat: Jl. Betoambari No. 36 Kota Baubau Sulawesi Tenggara kode Pos 93717. No. HP, WhatsApp: 08114030818 Email: ansar.suherman@gmail.com

\section{PENDAHULUAN}

Buton Selatan merupakan daerah otonomi baru yang baru mekar pada tahun 2014 dari Kabupaten Buton, Kabupaten Buton Selatan terdiri dari 7 (tujuh) Kecamatan yaitu Kecamatan Batauga, Kecamatan Sampolawa, Kecamatan Lapandewa, Kecamatan Kadatua, Kecamatan Siompu, Kecamatan Siompu Barat dan Kecamatan Batuatas. Kabupaten Buton Selatan beribukota di Kecamatan Batauga dimana Kelurahan Busoa termaksud wilaya kecamatan Batauga, Buton Selatan pertama kali melaksanakan pemilihan Bupati pada tahu 2017. Di Kelurahan Busoa ada beberapa cabang ranting partai antara lain: Parati Amanat Naisonal(PAN), Partai Demokrat, Partai Persatuan Pembangunan (PPP), Partai Naisonal Demokrasi(Nasdem).

Pemilu adalah sarana yang pemenuhan hak warga negara Indonesia untuk terlibat dalam pemerintahan. Pelaksanaan pemilu secara langsung oleh rakyat merupakan suatu bentuk partisipasi politik. Hal ini menunjukkan pemilu dapat dikatakan sebagai sarana bagi rakyat untuk ikut berpartisipasi dalam politik. Untuk itu, pemilu tidak dapat dipisahkan dari kesediaan dan keikutsertaan rakyat dalam menggunakan hak pilihnya.

Tiap pelaksanaan pemilu tentu akan terdapat perbedaan jumlah pemilih berdasarkan jumlah penduduk yang terdaftar sebagai pemilih. Salah satunya yakni baik dipengaruhi pengurangan jumlah pemilih karena adanya jumlah kematian, maupun adanya penambahan jumlah daftar pemilih karena adanya pemilih baru atau pemilih pemula.

Mengingat pemilih umum merupakan pemilih yang sangat potensial dalam perolehan suara pada pemilu. Permasalahan ini juga dirasa telah menjadi permasalahan yang sama di berbagai daerah termasuk Kabuputen Buton Selatan sebagai daerah otonomi baru.

Partai politik selaku wadah yang salah satu fungsinya yaitu sarana sosialisasi politik. Diharapkan partai politik mengetahui permasalahan pemilih umum ini, yang jika dilihat dari sudut pandang partai politik permasalahan ini juga sekaligus merupakan peluang besar karena potensialnya pemilih umum ini dalam perolehan suara pada pemilu. Disinilah letak dari peran partai politik sebagai sarana sosialisasi politik.

Peran partai politik disamping sebagai sarana sosialisasi politik juga merupakan salah satu struktur politik yang memberikan pendidikan politik, baik lewat penataran, kaderisasi, ceramah, dan diskusi maupun lewat pengalaman praktis dalam mengikuti kegiatan praktis partai politik yang bersangkutan seperti rapat dan kampanye.

Menurut Husin (2014) Partai Politik memiliki fungsi sebagai sarana sosialisasi politik yang merupakan proses dimana seseorang memperoleh pandangan, dan nilai-nilai dari masyarakat. Lewat proses ini diharapkan partai politik dapat membantu peningkatan identitas nasional dan integrasi nasional.

Beragam upaya dilakukan partai politik mulai memberikan citra positif dengan gerakan sosial 
kemasyarakat, mempublikasikan ketenaran figur atau tokoh calon pemimpin, bahkan akhir-akhir ini maraknya partai politik yang merekrut kader dari kalangan selebriti yang sudah populer, membuat iklan, lagu, spanduk, juga menggunakan atributatribut sosialisasi politik lain yang tidak kalah menarik guna memperoleh simpati dari para pemilih umum.

Atribut-atribut sosialisasi politik yang digunakan partai politik guna mendukung kegiatan sosialisasi politik mereka kini sudah sangat beragam. Tidak hanya menggunakan media cetak saja, akan tetapi kini atribut sosialisasi politik yang akhir-akhir ini banyak beredar meliputi juga media elektronik dan juga media on-line/internet.

Semakin banyaknya atribut sosialisasi politik memunculkan terbuka luasnya pula peluang keberhasilan dalam menarik simpati pemilih pemula. Namun juga dapat memunculkan masalah baru yakni semakin beragam pula persepsi pemilih umum itu sendiri terhadap atribut sosialisasi politik yang digunakan partai-partai politik.

Apabila definisi komunikasi dan definisi politik itu kita kaitkan dengan komunikasi politik, maka akan terdapat suatu rumusan sebagai berikut: Komunikasi politik adalah komunikasi yang diarahkan kepada pencapaian suatu pengaruh sedemikian rupa, sehingga masalah yang dibahas oleh jenis kegiatan komunikasi ini, dapat mengikat semua warganya melalui suatu sanksi yang ditentukan bersama oleh lembaga-lembaga politik. Mengenai komunikasi politik ini (political communication) Kantaprawira memfokuskan pada kegunaanya, yaitu untuk menghubungkan pikiran politik yang

hidup dalam masyarakat, baik pikiran intra golongan, institusi, asosiasi, ataupun sektor kehidupan politik masyarakat dengan sektor kehidupan politik pemerintah.

Dengan demikian segala pola pemikiran, ide atau upaya untuk mencapai pengaruh, hanya dengan komunikasi dapat tercapainya segala sesuatu yang diharapkan, karena pada hakikatnya segala pikiran atau ide dan kebijakan (policy) harus ada yang menyampaikan dan ada yang menerimanya, proses tersebut adalah proses komunikasi.

Dilihat dari tujuan politik "an sich", maka hakikat komunikasi politik adalah upaya kelompok manusia yang mempunyai orientasi pemikiran politik atau ideology tertentu dalam rangka menguasai dan atau memperoleh kekuasaan, dengan kekuatan mana tujuan pemikiran politik dan ideology tersebut dapat diwujudkan.

Lasswell, memandang orientasi komunikasi politik telah menjadikan dua hal sangat jelas: pertama, bahwa komunikasi politik selalu berorientasi pada nilai atau berusaha mencapai tujuan, nilai-nilai dan tujuan itu sendiri dibentuk di dalam dan oleh proses perilaku yang sesungguhnya merupakan suatu bagian, dan kedua, bahwa komunikai politik bertujuan menjangkau masa depan dan bersifat mengantisipasi serta berhubungan dengan masa lampau dan senantiasa memperhatikan kejadian masa lalu.

Surbakti menjelakan bahwa komunikasi politik, ialah proses penyampaian informasi mengenai politik dari pemerintah kepada masyarakat dan dari 
masyarakat kepada pemerintah. Dalam melaksanakan fungsi ini, partai politik tidak menyampaikan begitu saja segala informasi dari pemerintah kepada masyarakat atau dari masyarakat kepada pemerintah, tetapi merumuskan sedemikian rupa sehingga penerima informasi (komunikan) dapat dengan mudah memahami dan memanfaatkan. Dengan demikian, segala kebijakan pemerintah yang biasanya dirumuskan dalam bahasa teknis dapat diterjemahkan ke dalam bahasa yang dipahami masyarakat. Sebaliknya, segala aspirasi, keluhan dan tuntutan masyarakat yang biasanya tidak terumuskan dalam bahasa yang dapat dipahami oleh pemerintah. Jadi, proses kmunikasi politik antara pemerintah dan masyarakat dapat berlangsung secara efektif melalui partai politik.

Banyak ahli memberikan pengertian mengenai konsep partisipasi. Bila dilihat dari asal katanya, kata partisipasi berasal dari kata bahasa Inggris "participation" yang berarti pengambilan bagian, pengikutsertaan (John M. Echols \& Hasan Shadily, 2000).

Partisipasi berarti peran serta seseorang atau kelompok masyarakat dalam proses pembangunan baik dalam bentuk pernyataan maupun dalam bentuk kegiatan dengan memberi masukan pikiran, tenaga, waktu, keahlian, modal dan atau materi, serta ikut memanfaatkan dan menikmati hasil -hasil pembangunan ( Sumaryadi, 2010).

Pengertian tentang partisipasi dikemukakan oleh Fasli Djalal dan Dedi Supriadi, (2001) dimana partisipasi dapat juga berarti bahwa pembuat keputusan menyarankan kelompok atau masyarakat ikut terlibat dalam bentuk penyampaian saran dan pendapat, barang, keterampilan, bahan dan jasa. Partisipasi dapat juga berarti bahwa kelompok mengenal masalah mereka sendiri, mengkaji pilihan mereka, membuat keputusan, dan memecahkan masalahnya. H.A.R.Tilaar, mengungkapkan partisipasi adalah sebagai wujud dari keinginan untuk mengembangkan demokrasi melalui proses desentralisasi dimana diupayakan antara lain perlunya perencanaan dari bawah (bottom-up) dengan mengikutsertakan masyarakat dalam proses perencanaan dan pembangunan masyarakatnya.

Menurut Sundariningrum dalam Sugiyah (2001) mengklasifikasikan partisipasi menjadi 2 (dua) berdasarkan cara keterlibatannya, yaitu :

\section{Partisipasi Langsung}

Partisipasi yang terjadi apabila individu menampilkan kegiatan tertentu dalam proses partisipasi. Partisipasi ini terjadi apabila setiap orang dapat mengajukan pandangan, membahas pokok permasalahan, mengajukan keberatan terhadap keinginan orang lain atau terhadap ucapannya.

\section{Partisipasi tidak langsung}

Partisipasi yang terjadi apabila individu mendelegasikan hak partisipasinya. Cohen dan Uphoff yang dikutip oleh Siti Irene Astuti D (2011) membedakan patisipasi menjadi empat jenis, yaitu pertama, partisipasi dalam pengambilan keputusan. Kedua, partisipasi dalam pelaksanaan. Ketiga, partisipasi dalam pengambilan pemanfaatan. Dan Keempat, partisipasi dalam evaluasi. 
Pertama, partisipasi dalam pengambilan keputusan. Partisipasi ini terutama berkaitan dengan penentuan alternatif dengan masyarakat berkaitan dengan gagasan atau ide yang menyangkut kepentingan bersama. Wujud partisipasi dalam pengambilan keputusan ini antara lain seperti ikut menyumbangkan gagasan atau pemikiran, kehadiran dalam rapat, diskusi dan tanggapan atau penolakan terhadap program yang ditawarkan. Kedua, partisipasi dalam pelaksanaan meliputi menggerakkan sumber daya dana, kegiatan administrasi, koordinasi dan penjabaran program. Partisipasi dalam pelaksanaan merupakan kelanjutan dalam rencana yang telah digagas sebelumnya baik yang berkaitan dengan perencanaan, pelaksanaan maupun tujuan. Ketiga, partisipasi dalam pengambilan manfaat. Partisipasi dalam pengambilan manfaat tidak lepas dari hasil pelaksanaan yang telah dicapai baik yang berkaitan dengan kualitas maupun kuantitas. Dari segi kualitas dapat dilihat dari output, sedangkan dari segi kuantitas dapat dilihat dari presentase keberhasilan program. Keempat, partisipasi dalam evaluasi. Partisipasi dalam evaluasi ini berkaitan dengan pelaksanaan pogram yang sudah direncanakan sebelumnya. Partisipasi dalam evaluasi ini bertujuan untuk mengetahui ketercapaian program yang sudah direncanakan sebelumnya.

Berdasarkan beberapa definisi di atas maka dapat disimpulkan bahwa partisipasi adalah keterlibatan suatu individu atau kelompok dalam pencapaian tujuan dan adanya pembagian kewenangan atau tanggung jawab bersama.

Bentuk partisipasi menurut Effendi yang dikutip oleh Siti Irene Astuti D (2011), terbagi atas:

\section{1) Partisipasi Vertikal}

Partisipasi vertikal terjadi dalam bentuk kondisi tertentu masyarakat terlibat atau mengambil bagian dalam suatu program pihak lain, dalam hubungan dimana masyarakat berada sebagai status bawahan, pengikut, atau klien.

2) Partisipasi horizontal

Partisipasi horizontal, masyarakat mempunyai prakarsa dimana setiap anggota atau kelompok masyarakat berpartisipasi horizontal satu dengan yang lainnya.

Menurut Basrowi yang dikutip Siti Irene Astuti D (2011), partisipasi masyarakat dilihat dari bentuknya dapat dibedakan menjadi dua, yaitu:

1) Partisipasi fisik

Partisipasi fisik adalah partisipasi masyarakat (orang tua) dalam bentuk menyelenggarakan usaha-usaha pendidikan, seperti mendirikan dan menyelenggarakan usaha sekolah.

\section{2) Partisipasi non fisik}

Partisipasi non fisik adalah partisipasi keikutsertaan masyarakat dalam menentukan arah dan pendidikan nasional dan meratanya animo masyarakat untuk menuntut ilmu pengetahuan melalui pendidikan, sehingga pemerintah tidak ada kesulitan mengarahkan rakyat untuk bersekolah. 


\section{METODE PENELITIAN}

\section{A. Jenis Peniltian}

Jenis Penilitian yang digunakan dalam penyusunan Proposal ini adalah jenis penilitian kuantitatif dengan menggunakan data-data yang berhubungan dengan jumlah pemilih umum tahun 2017 di keluarahan Busoa kecamatan Batauga kabupaten Buton Selatan. Menurut Sugiono (2008), metode kuantitatif adalah pendekatan ilmiah yang memandang suatu realitas itu dapat diklasifikasikan, konkrit, teramati dan terukur,hubungan variabelnya bersifat sebab akibat dimana data penelitiannya berupa angkaangka dan analisisnya menggunakan statistik.

\section{B. Variabel Penelitian}

Varabel penelitian adalah segala sesuatu yang berbentuk apa saja yang ditetapkan oleh peneliti untuk dipelajari sehingga diperoleh informasi tentang hal tersebut, kemudian ditarik kesimpulan (Sugiyono,2013: 38). Variabel yang digunakan dalam penelitian dapat diklasifikasikan menjadi: (1) variabel independen (bebas), yaitu variabel yang menjelaskan dan memengaruhi variabel lain, (2) variabel dependen (terikat), yaitu variabel yang dijelaskan dan dipengaruhioleh variabel independen.

\section{Variabel Independen}

Variabel independen adalah variabel yang disebut sebagai variabel stimulus, predikator, dan anteseden. Variabel ini memengaruhi atau yang menjadi sebab perubahannya atau timbulnya variabel dependen (Sugiyono, 2013: 39). James W. Zanden (dalam Damsar, 2010: 152) mendefenisikan sosialisasi sebagai suatu proses interaksi sosial dengan mana orang memperoleh pengetahuan, sikap, nilai, dan perilaku esensial untuk keikutsertaan (partisipasi) efektif dalam masyarakat Variabel independen dalam penelitian ini adalah Sosialisasi Partai Politik (X)

\section{Variabel Dependen}

Variabel dependen sering disebut sebagai variabel output, kriteria, dan konsekuen. Dalam bahasa Indonesia sering disebut sebagai variabel terikat, Variabel terikat merupakan variabel yang dipengaruhi atau yang menjadi akibat, karena adanya variabel bebas (Sugiyono, 2013: 39).

Variabel dependen dalam penelitian ini adalah Partisipasi Pemilih umum (Y). Berdasarkan pasal 1 ayat 25 Undang-Undang No. 8 tahun 2012 tentang Pemilihan Umum Anggota DPR, DPD dan DPRD mengatakan bahwa pemilih adalah warga negara indonesia yang telah genap berumur 17 (tujuh belas ) tahun atau lebih atau sudah/perna kawin.

\section{Definisi Operasional Variabel Penelitian}

\section{a. Definisi Operasiaonal Variabel Penelitian}

Definisi operasional variabel penelitian adalah suatu definisi yang diberikan kepada suatu variabel atau konstrak dengan cara memberikan arti, atau menspesifikasikan kegiatan, ataupun memberikan suatu operasional yang diperlukan untuk mengukur konstrak atau variabel tersebut. (Moh. Nazir; 2003:126).

Moh. Nazir mengatakan terdapat tiga buah pola dalam memberikan definisi operasional terhadap suatu konstrak atau variabel, yaitu : 
1. Definisi yang dibuat berdasarkan kegiatan kegiatan lain yang terjadi, atau kegiatan yang harus dilakukan, atau yang tidak dilakukan untuk memperoleh konstrak yang didefinisikan. Contohnya, Politik adalah kegiatan yang menyangkut cara bagaimana kelompok-kelompok mencapai keputusan-keputusan yang bersifat kolektif dan mengikat melalui usaha untuk mendamaikan perbedaan-perbedaan diantara anggota-anggotanya.

2. Definisi yang disusun berdasar atas sifat atau atas cara bekerjanya hal yang didefinisikan. Contohnya, Pemilu merupakan sarana pelaksanaan kedaulatan rakyat dimana rakyat dapat memilih pemimpin politik secara langsung

3. Definisi yang disusun atas dasar bagaimana hal yang didefinisikan itu muncul. Contohnya, sosialisai politik adalah proses pembentukan sikap orentasi politik para anggota masyarakat

\section{Populasi dan Sampel}

\section{Populasi}

Populasi dari Skripsi Penilitian ini adalah 900 orang wajib pilih yang ada di Kelurahan Busoa kecamatan Batauga kabupaten Buton Selatan.

\section{Sampel}

Karna jumlah populasi besar maka sampel dalam penelitian ini diambil dengan menggunakan teknik Simple Random Sampling. Dikataka simple (sederhana) karena pengambilan anggota sampel dari populasi dilakukan secara acak tanpa memperhatikan strata yang ada dalam populasi itu. Cara ini dilakukan bila anggota populasi dianggap homogen. (Sugiyono, 2014:123). Besarnya sampel ditetapkan dengan menggunakan rumus Taro Yamane atau Slovin dalam Riduwan (2007:65) sebagai berikut:

$n=\frac{N}{\mathrm{~N} \cdot \mathrm{d}^{2}+1}$

Keterangan:

$$
\begin{array}{ll}
\mathrm{n} & =\text { Jumlah sampel } \\
\mathrm{N} & =\text { Jumlah populasi } \\
\mathrm{d}^{2} & =\text { Presisi (ditetapkan } 10 \%
\end{array}
$$

dengan tingkat kepercayaan 95\%)

Berdasarkan rumus tersebut diperoleh jumlah sampel sebagai berikut.

$n=\frac{N}{\mathrm{~N} \cdot \mathrm{d}^{2}+1}=\frac{900}{(900) 0,1^{2}+1}=\frac{900}{10}=90$

Jadi sampel yang digunakan dalam penelitian ini adalah 90 orang.

\section{E. Instrumen Penelitian}

Menurut Suharsimi Arikunto (2003:136), Instrumen adalah fasilitias yang digunakan oleh penulis dalam mengumpulkan data agar pekerjaannya lebih mudah dan hasilnya lebih baik, dalam arti lebih cermat, lengkap, dan sistematis sehingga lebih mudah diolah. Instrumen yang digunakan dalam penelitian ini adalah kusioner (angket), yakni sejumlah pertanyaan tertulis yang digunakan untuk memperoleh informasi dari responden. Kusioner yang dipakai dalam penelitian ini adalah kusioner yang berkaitan dengan partisipasin pemilih umum.

Angket yang akan digunakan dalam penelitian ini adalah angket berbentuk skala Likert dengan pertanyaan bersifat tertutup yaitu jawaban atas pertanyaan yang diajukan sudah disediakan. 
Subyek penelitian hanya diminta untuk memilih salah satu jawaban yang sesuai dengan dirinya. Dalam penelitian ini, alternatif jawaban yang digunakan terdiri dari 4 alternatif jawaban yaitu a, b, c, dan d. Adapun skor untuk setiap butir soal adalah sebagai berikut.

Tabel 1. Skor untuk Setiap Butir Soal pada Skala Likert

\begin{tabular}{|c|c|c|}
\hline Jawaban & $\begin{array}{c}\text { Skor Pertanyaan } \\
\text { Positif }\end{array}$ & $\begin{array}{c}\text { Skor Pertanyaan } \\
\text { Negatif }\end{array}$ \\
\hline A & 4 & 1 \\
\hline B & 3 & 2 \\
\hline C & 2 & 3 \\
\hline D & 1 & 4 \\
\hline
\end{tabular}

Teknik ini ditujukan kepada pemilih umum dan digunakan untuk mengumpulkan data mengenai politik dan partisipasi pemilih umum di Kelurahan Busoa Kecamatan Batauga Kabupaten Buton Selatan.

Adapun kisi-kisi instrumen adalah sebagai berikut:

Tabel 2. Kisi-kisi instrumen penelitian

\begin{tabular}{|c|c|c|c|c|}
\hline \multirow{2}{*}{ Variabel } & \multirow{2}{*}{ Indikator } & \multicolumn{2}{|c|}{ No. Item } & \multirow{2}{*}{ Jumlah } \\
\hline & & $(+)$ & $(-)$ & \\
\hline \multirow{3}{*}{$\begin{array}{c}\text { Sosialisasi } \\
\text { Parta } \\
\text { Politik } \\
\text { (X) }\end{array}$} & $\begin{array}{c}\text { Pemahaman } \\
\text { politik }\end{array}$ & $\begin{array}{c}1,2,3, \\
4,5\end{array}$ & & 5 \\
\hline & $\begin{array}{l}\text { Komunikasih } \\
\text { politik }\end{array}$ & $\begin{array}{c}6,7,8 \\
9,10\end{array}$ & & 5 \\
\hline & Jumlah & 10 & & 10 \\
\hline \multirow[t]{2}{*}{$\begin{array}{l}\text { Partisipasi } \\
\text { pemelih } \\
\text { umum (Y) }\end{array}$} & $\begin{array}{l}\text { Daftar pemilih } \\
\text { tetap (DPT) di } \\
\text { Kelurahan } \\
\text { Busoa }\end{array}$ & - & - & - \\
\hline & Jumlah & - & - & - \\
\hline
\end{tabular}

\section{F. Teknik Pengumpulan Data}

Teknik pengumpulan data yang digunakan dalam penelitian ini adalah kuesioner (angket) dan dokumentasi. Uraian lebih lanjut adalah sebagai berikut.

\section{Kuesioner (angket)}

Sugiyono (2014:193) mendefinisikan "kuesioner atau angket sebagai teknik pengumpulan data yang dilakukan dengan cara memberi seperangkat pertanyaan atau pernyataan tertulis kepada responden untuk dijawabnya". Teknik ini ditujukan kepada pemilih pemula dan digunakan untuk mengumpulkan data mengenai politik dan partisipasi pemilih pemula di Kelrahan Busoa Kecamatan Batauga Kabupaten Buton Selatan.

\section{Dokumentasi}

Riduwan (2013:77) menyatakan bahwa "Dokumentasi ditujukan untuk memperoleh data langsung dari tempat penelitian, meliputi bukubuku yang relevan, peraturan-peraturan, laporan kegiatan, foto-foto, film dokumenter, data yang relevan”. Arikunto (2013:274) berpendapat bahwa "dokumentasi digunakan untuk mencari data mengenai hal-hal atau variabel yang berupa, catatan, transkrip, buku, surat kabar, majalah, prasasti, notulen rapat, agenda, dan sebagainya". Metode ini digunakan untuk mengumpulkan beberapa data mengenai daftar pemilih tetap, fotofoto kegiatan, dan lain sebagainya yang ada di kelurahan Busoa

\section{G. Teknik Analisis Data}

Analisis data merupakan langkah yang sangat penting dalam penelitian, terutama apabila 
penelitian tersebut bermaksud untuk mengambil kesimpulan dari masalah yang diteliti. Untuk menganalisis data diperlukan suatu cara atau metode analisis data. Metode analisis data digunakan untuk mengubah atau menganalisis data hasil penelitian agara dapat diinteprestasikan, sehingga laporan yang dihasilkan mudah dipahami.

Data yang diperoleh dari penelitian ini selanjutnya akan dianilisis yaitu analisis data secara deskriptif dengan menggunaka regresi linear sederahana.

Untuk mengetahui pengaruh politik terhadap partisipasi pemilih pemulah dengan menggunakan analisis regresi linear sederhana dengan rumus : $\mathrm{Y}=\alpha+\mathrm{Bx}$ (Sugiyono, 2003:244)

Keterangan :

$\mathrm{X}=$ variabel bebas (sosialisasi partai politik) $\mathrm{Y}=$ variabel terikat (partisipasi pemilih umum)

$\alpha=$ nilai konstant (nilai $\mathrm{Y}$ taksiran pada saat $\mathrm{X}=0$ )

$\mathrm{b}=$ koefisien fariabel $\mathrm{X}$

untuk mengetahui niai $\alpha$ dan $b$ yakni dengan rumus :

$$
\begin{aligned}
& \alpha=\frac{\sum Y-b \sum X}{n} \\
& \mathrm{~b}=\frac{n \sum X Y-\sum X \sum Y}{n \sum X^{2}-\left(\sum X^{2}\right)}
\end{aligned}
$$

Selanjutnya untuk megetahui hubungan antara sosialisasi parti politik (X) partisipasi pemilih umum (Y), maka dapat menggunakan analisis korelasi product of moment dengan rumus sebagai berikut :

$$
r_{x y}=\frac{n\left(\sum X Y\right)-\left(\sum X\right)\left(\sum Y\right.}{\left.\sqrt{\left[n\left(\sum X^{2}\right)\right.}-\left(\sum X\right)^{2}\right]\left[n\left(\sum Y^{2}\right)-\left(\sum Y\right)^{2}\right)}
$$

Keterangan :

$$
\begin{array}{ll}
\mathrm{R}_{\mathrm{xy}}= & \text { Koefisien Korelasi } \\
\sum \mathrm{X}= & \text { Jumlah skor variabel } \mathrm{X} \\
\sum \mathrm{Y}= & \text { Jumlah skor variabel } \mathrm{Y} \\
\sum \mathrm{XY}= & \text { Jumlah hasil skor varibael } \mathrm{X} \text { dan } \\
& \text { skor variabel } \mathrm{Y} \\
\sum \mathrm{X}^{2} \quad & \text { Jumlah skor variabel } \mathrm{X} \text { yang } \\
& \text { dikuadradkan } \\
\sum \mathrm{Y}^{2}= & \text { Jumlah skor variabel } \mathrm{Y} \text { yang } \\
& \text { dikuadradkan } \\
\mathrm{n} & =\text { Jumlah Sampel }
\end{array}
$$

Setelah diperoleh angka indeks atau koefisien atau koefisien korelasi “ $\mathrm{r}$ " product moment mmaka dilakukan interprestasi data secara sederhana yaitu dengan hasi penelitian dengan angak indeks interprestasi " $\mathrm{r}$ " product moment di bawah ini :

Tabel 3. Interprestasi Data

\begin{tabular}{|c|c|}
\hline $\begin{array}{c}\text { Besarnya "r" product } \\
\text { moment }\left(\mathrm{r}_{\mathrm{xy}}\right)\end{array}$ & Tingkatan Hubungan \\
\hline $0,00-0,199$ & Sangat Rendah \\
\hline $0,20-0,399$ & Rendah \\
\hline $0,40-0,599$ & Cukup \\
\hline $0,60-0,799$ & Kuat \\
\hline $0,80-1,00$ & Sangat Kuat \\
\hline
\end{tabular}

\section{A. Waktu Dan Tempat}

Penelitian ini akan dilaksanakan dari bulan agustus 2017 sampai dengan september 2017. Tempat penelitian di Kelurahan Busoa Kecamatan Batauga Kabupaten Buton Selatan.

\section{HASIL DAN PEMBAHASAN}


Masyarakat kelurahan Busoa memiliki keragaman etnis masyrakat Buton, di antaranya terdapat beberapa suku yaitu Wolio, Cia-Cia, dan rumpun suku Muna. Hal dapat diamati berdasarkan kegunaan bahasa yang digunakan keseharian mayarakat yang ada di Kelurahan Busoa.

Penduduk kelurahan Busoa tergolong penduduk yang cukup besar jumlahnya, dimana secara keseluruhan jumlah penduduk kelurahan Busoa berjumlah 1.717 jiwa dengan jumlah kepala keluarga (KK) 244 kepala keluarga, jumlah penduduk kelurahan Busoa termaksud salah satu jumlah penduduk terbesar di Kecamatan Batauga..

Tabel 4.

\section{Data penduduk Kelurahan Busoa Menurut} Umur Dan Jenis Kelamin

\begin{tabular}{|c|c|c|c|c|}
\hline \multirow[t]{2}{*}{ No } & \multirow{2}{*}{$\begin{array}{c}\text { Kelompok } \\
\text { Umur }\end{array}$} & \multicolumn{2}{|c|}{ Jenis Kelamin } & \multirow{2}{*}{$\begin{array}{l}\text { Jumlah } \\
\text { Jiwa }\end{array}$} \\
\hline & & $\begin{array}{l}\text { Laki- } \\
\text { Laki }\end{array}$ & Perempuan & \\
\hline 1 & $0-4$ & 101 & 91 & 192 \\
\hline 2 & $5-9$ & 104 & 105 & 209 \\
\hline 3 & $10-15$ & 103 & 104 & 207 \\
\hline 4 & $15-20$ & 77 & 71 & 148 \\
\hline 5 & $21-25$ & 75 & 70 & 145 \\
\hline 6 & $26-30$ & 73 & 76 & 179 \\
\hline 7 & $31-35$ & 56 & 52 & 108 \\
\hline 8 & $36-40$ & 54 & 49 & 103 \\
\hline 9 & $41-45$ & 51 & 49 & 100 \\
\hline 10 & $46-49$ & 57 & 55 & 112 \\
\hline 11 & $50-55$ & 42 & 45 & 87 \\
\hline 12 & $56-59$ & 37 & 34 & 71 \\
\hline 13 & 60 keatas & 41 & 45 & 86 \\
\hline \multicolumn{2}{|r|}{ Jumlah } & 871 & 846 & 1.717 \\
\hline
\end{tabular}

Sumber : Kantor Keluarahan Busoa, Desember 2017

Daerah kelurahan Busoa termaksud daerah yang mulai menujukan tingkat pendidikan kearah yang berkembang dibanding sepuluh tahun lalu, perkembangan ini karena ada kesadaran masyarakat betapa pentingnya pendidikan.
Untuk merngetahui sejauh mana pendidikan masyarakat kelurahan Busoa dapat diliahat pada tabel berikut :

Tabel 5.

\section{Data Penduduk Kelurahan Busoa Menurut Tingkat Pendidikan}

\begin{tabular}{|l|l|c|c|}
\hline No & \multicolumn{1}{|c|}{$\begin{array}{c}\text { Tingkat } \\
\text { Pendidikan }\end{array}$} & $\begin{array}{l}\text { Jumlah } \\
\text { jiwa }\end{array}$ & $\begin{array}{c}\text { Peesentase } \\
(\mathbf{\%})\end{array}$ \\
\hline 1 & Belum sekolah & 195 & 11,35 \\
\hline 2 & $\begin{array}{l}\text { Belum / Tidak } \\
\text { Tamat SD }\end{array}$ & 234 & 13,62 \\
\hline 3 & Tamat SD & 354 & 20,61 \\
\hline 4 & Tamat SLTP & 302 & 17,58 \\
\hline 5 & Tamat SLTA & 418 & 24,34 \\
\hline 6 & $\begin{array}{l}\text { Sarjana Muda D3, } \\
\text { D2 }\end{array}$ & 96 & 5,70 \\
\hline 7 & Sarjana ( S1 ) & 116 & 6,75 \\
\hline & JUMLAH & $\mathbf{1 7 1 7}$ & $\mathbf{1 0 0}$ \\
\hline
\end{tabular}

Data : kantor kelurahan Busoa 2017

Dari tersebut dapat dilihat tingkat prndidikan pendudduk kelurahan Busoa pada tahun 2016-2017 adalah penduduk yang secara berturut-turut adalah penduduk yang belum sekolah yaitu sebanyak 195 orang (11,3\%5). Penduduk yang belum tamat sekolah yaitu sebanyak 234 orang $(13,62 \%)$. Penduduk yang tamat sekolah dasar yaitu sebanyak 354 orang $(20,61 \%)$. Penduduk yang tamat STLA yaitu sebanyak 302 orang $(17,58 \%)$. Penduduk yang tamat SLTA 418 orang $(24,34 \%)$. Penduduk sarjana muda D3, D2 yaitun sebanyak 96 orang $(5,70 \%)$. Penduduk pendidikan sarjana 116 orang $(6,75 \%)$.

Dari uraian tersebut maka secara umum bahwa mayoritas masyarakat Kelurahan Busoa adalah tamatan SLTA yaitu sebanyak 418 orang $(24,34 \%)$.

1. Mata Pencaharian 
Mata pencaharian penduduk suatu daerah atau wilayah tertentu banyak dipengaruhi lingkungan mereka sehingga banyak dari masyarakat hanya dapat memenuhi kehidupanya sehari-harinya.

Demikian halnya yang terjadi di kelurahan busoa mayoritas penduduknya bermata pencaharian sebagai petani dan pencaharian penduduk yang lain misalnya Pegawai Negeri sipil (PNS), TNI, Polri, pedagang, tukang kayu dan tukang batu.

Untuk lebih jelasnya tentang gambaran mata pencaharian penduduk kelurahan Busoa dapat dilihat pada tabel di bawah ini :

Tabel 6.

Data penduduk kelurahan Busoa menurut mata pencaharian

\begin{tabular}{|l|l|l|l|}
\hline No & $\begin{array}{l}\text { Mata } \\
\text { pencaharian }\end{array}$ & Jumlah & $\begin{array}{l}\text { Persentase } \\
(\%)\end{array}$ \\
\hline 1 & Petani & 154 & 66,11 \\
\hline 2 & Pedagang & 19 & 7,78 \\
\hline 3 & $\begin{array}{l}\text { Pegawai/ } \\
\text { TNI/Polri }\end{array}$ & 41 & 16,80 \\
\hline 5 & $\begin{array}{l}\text { Tukang kayu } \\
\text { Tukang batu }\end{array}$ & 13 & 5,32 \\
\hline & Jumlah & 244 & 6,96 \\
\hline
\end{tabular}

Data : kantor kelurahan Busoa

Berdasarkan data tersebut jumlah penduduk Kelurahan Busoa di tinjau dari mata pencaharianya 154 orang ( $66,11 \%)$ penduduknya bermata pencaharian sebagai petani, sebagai pedagan 19 orang ( 7,78\%) sebagai Pegawai/TNI/Polri 41 orang (16,80\% ) penduduk sebagai tukang kayu 13 orang $(5,32 \%)$ dan penduduk sebagai tukang batu 17 orang $(6,96 \%)$

2. Kesehatan
Kesehatan adalah merupakan hal paling terpenting bagi manusia karena dengan keadaan sehat segala aktifitas akan berjalan dengan baik dan sebaliknya pula apabila keadaan tidak sehat segala aktifitas akan terganggu

Dari hasil penelitaian adan pengamatan penulis menemukan bahwa kesehatan masyarakat kelurahan busoa cukup baik. Hal ini di tandai dengan tingginya kesadaran masyarakat untuk mermperhatikan kesehatan lingkungan dan kesehatan tubuhnya .

\section{Sistem kekerabatan}

Dalam sistem kekerabatan masyarakat Busoa sebagaimana masyarakat Buton, masyarakat kelurahan Busoa juga merupakan hal yang memiliki unsur anutan yang sama dengan sukusuku lain di Buton. Dalam bahasa Wolio lebih kongkrit dikenal dengan istilah "Siwulu umane", yang berarti garis keturunan laki-laki atau Ayah. Perwujudannya dalam kehidupan budaya masyrakat Buton seperti halnya dalam adat Busoa terlihat dalam adat perkawinan yaitu melakuakan pelamaran adalah berasal dari pihak laki-laki.

Tentang penanaman-penanaman yang terdapat dalam rumpun keluarga yang menujukkan klasifikasi angkatn sebagai berikut :

1) Tolida saudara sepupu derajat pertama

2) Topendu yaitu saudara sepupu kedua.

3) Topentalu yaitu saudara sepupu derajat ketiga.

4) Poabaakano sudah termaksuak keluarga jauh dimana hal ini sudah terdapat pada hal keempat. 
Sedangkat penanaman atau istilah kekerabatan adalah :

1) Pinoana yaitu kemenakan (keponakan)

2) Pinoama yaitu paman

3) Pinoyina yaitu bibi (tante)

4) Pinompua yaitu cucu

5) Ompua kakek atau nenek

Bentuk-bentuk peristiwa atau penambahan ini masih tetap berlaku pada kalangan masyarakat Wolio, bahkan pada suku atau etnis lain di wilayah bekas Kesultanan Buton hanya saja dipengaruhi bahasa asal dari masing-masing etnis yang ada.

\section{partisipasi pemilih umum kelurahan Busoa}

\section{kecamatan Batauga kabupaten Buton Selatan}

\section{Sampel responden}

Sampel responden dimaksudkan untuk mengetahui lebih jauh mengenai objek yang diteliti. Berikut ini adalah sampel responden berdaarkan status dan jenis

Tabel 7.

Sampel responden

\begin{tabular}{|c|c|c|c|c|}
\hline \multirow{2}{*}{ NO } & STATUS & \multicolumn{2}{|c|}{ Jenis Kelamin } & \multirow{2}{*}{$\begin{array}{c}\text { JULA } \\
\text { ORANG }\end{array}$} \\
\cline { 3 - 4 } & Tokoh agama & 3 & - & 3 \\
\hline & $\begin{array}{c}\text { Tokoh } \\
\text { masyarakat }\end{array}$ & 10 & 3 & 13 \\
\hline & Tokoh pemuda & 35 & - & 35 \\
\hline & Pegawai & 3 & 2 & 5 \\
\hline & Pedagang & 4 & - & 4 \\
\hline & Petani & 20 & 10 & 30 \\
\hline & Jumlah & 75 & 15 & 90 \\
\hline
\end{tabular}

Data hasil penelitian 2017

Berdasarkan sampel responden di atas diketahui bahwa dari 90 orang responden, 75 orang responden diantaranya laki-laki dan 15 orang responden perempuan.

\section{Deskripsi Jawaban Responden}

Jawaban-jawaban responden mengenai variabel-variabel dalam penelitian ini akan diberikan skor menggunakan skala likert (lihat halaman 48), yaitu Alternatif jawaban A dengan skor 4, Alternatif jawaban B dengan skor 3, Alternatif jawaban C skor 2, Alternatif jawaban D dengan skor 1.

\section{Sosialisasi Partai Politik}

Jawaban variabel sosialisasi partai politik dapat dilihat pada tabel dibawah ini.

Tabel 8.

Deskripsi Jawaban Variabel Pendidikan

\begin{tabular}{|c|c|c|c|c|c|}
\hline & $\mathbf{A}$ & B & $\mathbf{C}$ & $\mathbf{D}$ & TOTAL \\
\hline $\begin{array}{l}\text { Ite } \\
\mathrm{m} 1\end{array}$ & 31 & 43 & $\begin{array}{l}1 \\
3\end{array}$ & 3 & 90 \\
\hline $\begin{array}{l}\text { Prese } \\
\text { ntase }\end{array}$ & $\begin{array}{c}34,4 \\
\%\end{array}$ & $\begin{array}{c}47,7 \\
\%\end{array}$ & $\begin{array}{l}14, \\
5 \%\end{array}$ & $\begin{array}{c}3,4 \\
\%\end{array}$ & $100 \%$ \\
\hline Item 2 & 33 & 37 & 15 & 5 & 90 \\
\hline $\begin{array}{l}\text { Prese } \\
\text { ntase }\end{array}$ & $\begin{array}{c}36,7 \\
\%\end{array}$ & $\begin{array}{c}41,1 \\
\%\end{array}$ & $\begin{array}{l}16 . \\
6 \%\end{array}$ & $\begin{array}{c}5,6 \\
\%\end{array}$ & $100 \%$ \\
\hline Item 3 & 42 & 28 & 16 & 14 & 90 \\
\hline $\begin{array}{l}\text { Prese } \\
\text { ntase }\end{array}$ & $\begin{array}{c}46,6 \\
\%\end{array}$ & $\begin{array}{c}31,2 \\
\%\end{array}$ & $\begin{array}{l}17, \\
7 \%\end{array}$ & $\begin{array}{l}14, \\
5 \%\end{array}$ & $100 \%$ \\
\hline Item 4 & 49 & 22 & 13 & 6 & 90 \\
\hline $\begin{array}{l}\text { Prese } \\
\text { ntase }\end{array}$ & $\begin{array}{c}54,5 \\
\%\end{array}$ & $\begin{array}{c}24,5 \\
\%\end{array}$ & $\begin{array}{l}14, \\
4 \%\end{array}$ & $\begin{array}{c}6,6 \\
\%\end{array}$ & $100 \%$ \\
\hline Item 5 & 29 & 43 & 16 & 2 & 90 \\
\hline $\begin{array}{l}\text { Prese } \\
\text { ntase }\end{array}$ & $\begin{array}{c}37,8 \\
\%\end{array}$ & $\begin{array}{c}47,8 \\
\%\end{array}$ & $\begin{array}{l}17, \\
7 \%\end{array}$ & $\begin{array}{c}2,2 \\
\%\end{array}$ & $100 \%$ \\
\hline
\end{tabular}

Hasil data penelitian 2017

Berdasarkan tabel 8. dapat di deskripsikan sebagai berikut:

1) Item satu dengan pernyataan "apakah anda mengerti pesan sosialisasi Partai politik yang memberi pengertian anda mengenai proses pemilihan umum" dengan presentase jawaban masing-masing responden menjawab A sebanyak 34.4\%, B sebanyak 47,7\%, C 
sebanyak 14,5\%, dan responden yang menjawab D sebanyak $3,4 \%$.

2) Item dua dengan pernyataan "Sejauhmana, partai politik meyakinkan anda terhadap materi sosialisasi politik yang disampaikan" dengan presentase masing-masing jawaban responden menjawab A sebanyak $36,7 \%$, B sebanyak $41,1 \%$, C sebanyak $16,6 \%$ dan responden yang menjawab D sebanyak $5,6 \%$.

3) Item tiga dengan pernyataan "apa anda mengerti gaya bahasa yang disampaikan partai politik saat sosialisasi" dengan presentase jawaban masing-masing responden menjawab A 46,6\%, B sebanyak 31,2\%, C sebanyak $417,7 \%$ dan menjawab D sebanyak $14,5 \%$.

4) Item empat dengan pernyataan "Bagaimana pendapat anda mengenai waktu yang dibutuhkan anggota partai politik untuk menyampaikan materi sosialisasi politik" dengan presentase jawaban masing-masing responden menjawab A sebanyak 54,5\%, B sebanyak $24,5 \%$, C sebanyak $14,4 \%$, dan yang menjawab D sebanyak 6,6\%.

5) Item lima dengan pernyataan "menurut anda bagaimana fikur calon bupati yang di perkenalkan partai politik saat sosialisasi" dengan presentase jawaban masing-masing responden menjawab A sebanyak 32,3\%, B sebanyak $47,8 \%$, C sebanyak $17,7 \%$ dan menjawab D sebanyak 2,2\%.

\section{Variabel Partisipasi pemilih umum}

Jawaban resonden Partisipasi politik dapat dilihat pada tabel dibawah ini
Tabel 9.

Deskrpsi variabel partisipasi pemilih umum (Y)

\begin{tabular}{|c|c|c|c|c|c|}
\hline & $\mathbf{A}$ & B & C & D & $\begin{array}{c}\text { TO } \\
\text { TA } \\
\text { L }\end{array}$ \\
\hline Item 1 & 34 & 38 & 15 & 1 & 90 \\
\hline $\begin{array}{l}\text { Prese } \\
\text { ntase }\end{array}$ & $\begin{array}{l}37, \\
8 \%\end{array}$ & $\begin{array}{l}42, \\
2 \%\end{array}$ & $\begin{array}{l}18, \\
9 \%\end{array}$ & $\begin{array}{l}\mathbf{1}, \\
\mathbf{1} \\
\%\end{array}$ & $\begin{array}{c}100 \\
\%\end{array}$ \\
\hline Item 2 & 11 & 68 & 11 & 0 & 90 \\
\hline $\begin{array}{l}\text { Prese } \\
\text { ntase }\end{array}$ & $\begin{array}{l}12, \\
2 \%\end{array}$ & $\begin{array}{l}75, \\
6 \%\end{array}$ & $\begin{array}{l}12, \\
2 \%\end{array}$ & $\begin{array}{l}0 \\
\%\end{array}$ & $\begin{array}{c}100 \\
\%\end{array}$ \\
\hline Item 3 & 68 & 10 & 5 & 7 & 90 \\
\hline $\begin{array}{l}\text { Prese } \\
\text { ntase }\end{array}$ & $\begin{array}{l}75, \\
5 \%\end{array}$ & $\begin{array}{l}11, \\
1 \%\end{array}$ & $\begin{array}{c}5,5 \\
\%\end{array}$ & $\begin{array}{l}7, \\
7 \\
\%\end{array}$ & $\begin{array}{c}100 \\
\%\end{array}$ \\
\hline Item 4 & 88 & 1 & 0 & 1 & 90 \\
\hline $\begin{array}{l}\text { Prese } \\
\text { ntase }\end{array}$ & $\begin{array}{l}97, \\
8 \%\end{array}$ & $\begin{array}{c}1,1 \\
\%\end{array}$ & $0 \%$ & $\begin{array}{c}1, \\
1 \\
\%\end{array}$ & $\begin{array}{c}100 \\
\%\end{array}$ \\
\hline Item 5 & 15 & 68 & 6 & 1 & 90 \\
\hline $\begin{array}{l}\text { Prese } \\
\text { ntase }\end{array}$ & $\begin{array}{l}16 . \\
7 \%\end{array}$ & $\begin{array}{l}75, \\
5 \%\end{array}$ & $\begin{array}{c}6,7 \\
\%\end{array}$ & $\begin{array}{l}1, \\
\mathbf{1}\end{array}$ & $\begin{array}{c}100 \\
\%\end{array}$ \\
\hline
\end{tabular}

Hasil data penelitian 2017

Berdasarkan tabel 5.6 dapat di deskripsikan sebagai berikut:

1) Item satu dengan pernyataan ". Apakah anda mengetahui gambar dan nomor urut calon bupati saat mencoblos" dengan responden 90 orang menjawab kuesioner dengan presentase masing - masing yaitu: A sebanyak 37,8\%, B sebanyak 42,2\%, C sebanyak $18,9 \%$ dan yang menjawab D sebanyak $1,1 \%$.

2) Item dua dengan pernyataan "Apakah sosialisasi pemilihan Bupati yang dilakukan partai politik menarik minat anda untuk memilih pada pemilihan Bupati Buton Selatan" dengan responden 90 orang menjawab kuesioner dengan presentase masing - masing yaitu: A senanyak 12,2\%, B sebanyak $75.6 \%$,C sebanyak 12,2\% dan yang menjawab D sebanyak $0 \%$. 
3) Item tiga dengan pernyataan “. Apakah anda memilih sesuai dengan hati nurani saat mencoblos salah satu calon bupati" dengan responden 90 orang menjawab kuesioner dengan presentase masing - masing yaitu: A sebanyak $75,5 \%$, B sebanyak 11,1\%, C sebnyak 5,5\% dan responden yang menjawab D sebanyak $7,7 \%$.

4) Item empat dengan pernyataan "apakah anda datang ke TPS dengan kesadaran sendiri untuk memilih" dengan responden 90 orang menjawab kuesioner dengan presentase masing - masing yaitu: A sebanyak 97,8\%, B sebanyak $1,1 \%$, C $0 \%$ dan responden yang menjawab D sebanyak $1,1 \%$.

5) Item lima dengan pernyataan "apakah anda datang ke TPS degan tepat waktu saat memilih" dengan responden 90 orang menjawab kuesioner dengan presentase masing - masing yaitu: A sebanyak 16,7\%, B sebanyak $75,5 \%$, C sebanyak $6,7 \%$ dan responden yang menjawab D sebanyak $1,1 \%$.

\section{Analisis Pengaruh Sosialisasi Partai Politik}

\section{Terhadap Partisipasi Pemilih Umum Pada}

pemilihan Bupati 2017 Di Kelurahan Busoa

Kecamatan Batauga Kabupaten Buton Selatan

\section{Analisis Hasil Uji Linieritas}

Uji kelinieran dengan hipotesis uji:

Ho : persamaan regresi tidak linier

H1 : persamaan regresi linier

Dengan kriteria Ho ditolak jika Nila signifikasi dari $F_{\text {hitung }}<$ nilai signifikasi yang ditentukan $=0,05$
Model regresi adalah linier, artinya bisa dikatakan model regresi linier partisipasi pemilih umum (Y) atas variabel partsiapsi partai politik (X) diperoleh Fhitung $=38,28$ Nilai signifikansi adalah $0,00<0,05$ maka Ho ditolak dan H1 diterima, artinya model regresi adalah linier. Dengan demikian berarti terdapat keberuntungan antara variabel partisipasi pemilih umum (Y ) atas variabel sosialisasi partai politik (X). Hasil penguji dilihat dari autput regresi SPSS windows tabel Anova sebagaimana ditujukan berikut.

\section{Tabel 10.}

ANOVA $^{\mathrm{a}}$

\begin{tabular}{|cc|c|c|c|c|c|}
\hline Model & $\begin{array}{c}\text { Sum of } \\
\text { Squares }\end{array}$ & Df & $\begin{array}{c}\text { Mean } \\
\text { Square }\end{array}$ & F & Sig. \\
\hline 1 & Regression & 75,043 & 1 & 75,043 & 38,8 &, $000^{b}$ \\
& & & & 28 & \\
& Residual & 170,079 & 88 & 1,933 & & \\
Total & 245,122 & 89 & & & \\
\hline
\end{tabular}

a. Dependent Variable: Partisipasi Pemilih Umum

b. Predictors: (Constant), Sosialisasi Partai Politik

\section{Keofisien Korelasi antar Variabel}

Berdasarkan hasil analisis diketahui korelasi antar varibel independen (X) dengan variabel (Y) di;lihat pada tabel berikut:

Tabel 11.

Koefisien Korelasi antar Variabel

\section{Correlations}

\begin{tabular}{|ll|l|l|}
\hline & & $\begin{array}{l}\text { Sosialisasi } \\
\text { Partai Politik }\end{array}$ & $\begin{array}{l}\text { Partisipasi } \\
\text { Pemilih } \\
\text { Umum }\end{array}$ \\
\hline $\begin{array}{l}\text { Sosialisasi } \\
\text { Partai }\end{array}$ & $\begin{array}{l}\text { Pearson } \\
\text { Correlation } \\
\text { Politik }\end{array}$ & 1 &, $553^{* * *}$ \\
& $\begin{array}{l}\text { Sig. (2- } \\
\text { tailed) }\end{array}$ & N &, 000 \\
Partisipasi & Pearson \\
Pemilih & Correlation \\
Umum & Sig. (2- &, $553^{* *}$ & 90 \\
& tailed) &, 000 & 1 \\
& N & 90 & 90 \\
\hline
\end{tabular}


**. Correlation is significant at the 0.01 level (2-tailed).

Berdasarkan tabel diatas diketahui bahwa partisipasi pemilih umum (Y) memiliki hungan positif dengan variabel sosialisasi partai politik (X) yang dengan korelasi 0,553 sehingga masuk dalam kategori cukup kuat. Berarti jika terjadi perubahan tingkat sosialisasi partai politik maka partisipasi pemilih umum akan mengalami perubahan. Artinya peningkatan pada variabel sosialisasi partai politik akan diikuti oleh peningkatan partisipasi pemilih umum atau sebaliknya.

Tingkat signifikasi korelasi dengan melihat angka signifikasi. Jika nilai signifikasi (nilai 2tailed) > 0,05 maka Ho diteriama dan jika nilai signifikasi (nilai 2-tailed) $<0,05$ maka Ho ditolak.

\section{Uji Koesfisien Determinasi}

Koefisiensi determinasi yang dimaksud dalam penelitian ini adalah derajat keterpengaruhan variabel bebas terhadap variabel terikat . hasil uji koefisien determinasi adalah sebagaimana ditujukan pada tabel berikut :

Tabel 12.

\begin{tabular}{|c|c|r|r|r|}
\hline Model & $\mathrm{R}$ & $\begin{array}{c}\mathrm{R} \\
\text { Square }\end{array}$ & $\begin{array}{c}\text { Adjusted R } \\
\text { Square }\end{array}$ & $\begin{array}{c}\text { Std. Error } \\
\text { of the } \\
\text { Estimate }\end{array}$ \\
\hline 1 &, $553^{\mathrm{a}}$ &, 306 &, 298 & 1,390 \\
\hline
\end{tabular}

a. Predictors: (Constant), Sosialisasi Partai Politik

Berdasarkan tabel di atas tampak nilai Koefisien determinasi $(\mathrm{R}$ Square $)=0,306$. Hal ini menjelaskan bahwa nilai partisispasi pemilih umum sebesar 30,6\% dipengaruhi oleh sosialisasi politik dan $60,4 \%$ dipengaruhi oleh faktor lain yang tidak diteliti dalam penelitian ini.

\section{Uji Hipotesis}

Uji hipotesis dimaksudkan untuk mengetahui signifikikasi pengaruh/kontribusi variabel bebas terhadap variabel terikat. Hasil pengujian hipotesis dilakukan melalui nilai Thitung dengan hipotesis:

Ho : tidak ada pengaruh positif yang signifikan antara sosialisasi partai politik terhadap terhadap partsipasi pemilih umum di Kelurahan Busoa.

H1 : ada pengaruh positif yang signifikan antara sosialisasi partai politik terhadap terhadap partsipasi pemilih umum di Kelurahan Busoa.

Tabel 4.10

Coefficients $^{\mathrm{a}}$

\begin{tabular}{|c|r|r|r|r|r|}
\hline \multirow{2}{*}{ Model } & \multicolumn{2}{|c|}{$\begin{array}{l}\text { Unstandardize } \\
\text { d Coefficients }\end{array}$} & $\begin{array}{c}\text { Standardi } \\
\text { zed } \\
\text { Coefficie } \\
\text { nts }\end{array}$ & t & Sig. \\
\cline { 2 - 5 } & $\mathrm{B}$ & $\begin{array}{r}\text { Std. } \\
\text { Error }\end{array}$ & Beta & & \\
\hline (Constant) & 9,745 & 1,133 & & 8,603 &, 000 \\
1 &, 443 &, 071 &, 553 & 6,231 &, 000 \\
$\begin{array}{l}\text { Sosialisasi } \\
\text { Partai } \\
\text { Politik }\end{array}$ & & & & & \\
\hline
\end{tabular}

a. Dependent Variable: Partisipasi Pemilih Umum

Berdasarkan Tabel 4.18, Hasil uji hipotesis dengan menggunakan uji-t menujukan bahwa Thitung pada variabel sosialisasi partai politik yaitu sebesar 6,231 dan signifikan pada angka 0,000. Dimana nilai signifikan lebih kecil dibandingkan angka signifikasi yang ditetapkan $(0,000<0,05)$. Maka dapat ditarik kesimpulan $\mathrm{H}_{1}$ diterima dan Ho di tolak. Artinya bahwa terdapat pengaruh yang positif antara variabel sosialisasi partai politik terhadap partisipasi pemilih umum.

\section{SIMPULAN}


Penelitian ini difokuskan pengaruh sosialisasi partai politik terhadap partisipasi pemilih umum pada pemilihan Bupati 2017 di Kelurahan Busoa Kecamatan Batauga Kabupaten Buton Selatan

Hasil uji hipotesis dengan menggunakan uji-t menujukan bahwa Thitung pada variabel sosialisasi partai politik yaitu sebesar 6,231 dan signifikan pada angka 0,000. Dimana nilai signifikan lebih kecil dibandingkan angka signifikasi yang ditetapkan $(0,000<0,05)$. Maka dapat ditarik kesimpulan $\mathrm{H}_{1}$ diterima dan $\mathrm{Ho}$ di tolak. Artinya bahwa terdapat pengaruh yang positif antara variabel sosialisasi partai politik terhadap partisipasi pemilih umum.

Berdasarkan hasil penelitian disarankan sebagai berikut :

a. Diharapkan dapat memberikan konstribusi dalam pengembangan Ilmu Politik, terutama yang berkaitan dengan pengaruh sosialisasi partai politik terhadap partisipasi pemilih umum.

b. Diharapkan dapat menjadi bahan masukan dan pertimbangan bagi partai politik dalam membuat strategi sosialisasi kepada pemilih umum.

\section{DAFTAR PUSTAKA}

Arikunto, Suharsimi. 2003. Prosedur Penelitian, Suatu Praktek. Jakarta: Bina Aksara.

Fasli Djalal dan Dedi Supriadi, 2001. Reformasi Pendidikan dalam konteks otonomi daerah. Depdiknas bapenas adiciptakaryanusa.Jakarta.

H.A.R.Tilaar. 2009. Kekuasaan pendidikan: Kajian Menejemen Pendidikan Nasional dalam Pusaran Kekuasaan. Jakarta: rinika Cipta.
John M. Echols dan Hassan Shadily. 2000. Kamus Inggris Indonesia An EnglishIndonesia Dictionary. Jakarta : PT. Gramedia.

Kantaprawira, Rusadi. 2004. Sistem Politik Indonesia: Suatu Model Pengantar. Bandung:Sinar Baru Algensindo

Menurut Husin 2014. Umar, Husein. 2014. Metode Penelitian Untuk Skripsi \& Tesis Bisnis Edisi ke 2. Jakarta:Rajawali Pers.

Moh Nazir. 2003. Metode Penelitian. Jakarta : Ghalia Indonesia, 2003

Riduwan dan Sunarto. 2011. Pengantar Statistika untuk Penelitian Pendidikan, Sosial, Ekonomi, Komunikasi, dan Bisnis. Bandung: Alfabeta

Sumaryadi, I Nyoman, 2010, Perencanaan Pembangunan Daerah Otonom dan Pemberdayaan Masyarakat. Jakarta: Penerbit Citra Utama

Sugiyah 2001. Partisipasi Komite Sekolah dalam penyelenggaraan Rintisan Sekolah Bertaraf Internasional di Sekolah Dasar (SD) Negeri IV Wates, Kabupaten Kolon Progo. Tesis. PPs-UNY

Sugiyono, 2013, Metodelogi Penelitian Kuantitatif, Kualitatif Dan $R \& D$. (Bandung: ALFABETA)

Siti Irene Astuti Dwiningrum. 2011. Desentralisasi dan Partisipasi Masyarakat dalam Pendidikan. Yogyakarta: Pustaka Pelajar. 